\title{
Identification of significant obstructive sleep apnoea in the obese patient: development of the novel DX-OSA score
}

\author{
Daniela D. Godoroja ${ }^{1}$, Dan Adrian Cioc $^{2}$ \\ ${ }^{1}$ Ponderas Hospital, Bucharest, Romania, University of Medicine and Pharmacy "Carol Davila” Bucharest, Romania \\ ${ }^{2}$ Emergency County Hospital, Targu-Mures, Romania
}

\begin{abstract}
Background and objectives. There is a high prevalence of undiagnosed obstructive sleep apnoea (OSA) in obese surgical patients. We investigated the extent to which anthropometric measurements can be used to identify the presence of significant OSA (Apnoea/Hypopnoea Index (AHI) $\geq 20$ ) in adult patients.

Materials and methods. We prospectively studied 1357 adult patients scheduled for elective laparoscopic bariatric surgery. Prior to surgery, body mass index (BMI), gender, neck circumference, STOP-Bang score, $\mathrm{SpO}_{2}$, neck and trunk fat (by dual X-ray absorptiometry) were recorded. All patients with a STOPBang score $\geq 5$ underwent polysomnography. Auto-titrated Positive Airway Pressure (APAP) therapy was instituted when AHI $\geq 20 / \mathrm{h}$. Predictors of OSA were identified and their cut-off values determined.

Results: In total, 1357 patients were screened; 345 patients underwent preoperative polysomnography; 190 had AHI $\geq 20 / \mathrm{h}$ and received APAP treatment. The novel Dual X-Ray-Obstructive Sleep Apnoea (DX-OSA) score was derived from the data. The score included 6 items: the STOP-Bang score, BMI, neck fat, trunk fat, baseline $\mathrm{SpO}_{2}$, and Expiratory Reserve Volume (ERV), and its sensitivity, specificity, positive-predictive values, negative-predictive values, likelihood ratios, and post-test probabilities determined. At a cut-off of 3, the DX-OSA score had the same sensitivity as the STOP-bang score, but better specificity. The lowest likelihood ratio was found for STOP-Bang and the highest for the DX-OSA score (OSA probability $>83 \%$ ).

Conclusion: The DX-OSA score may be useful for identifying obese patients with significant OSA who require CPAP (continuous positive airway pressure) treatment, and CPAP could be commenced without the need for polysomnography, therefore, without delaying surgery.
\end{abstract}

Keywords: obstructive sleep apnoea, obesity, continuous positive airway pressure

\section{Introduction}

Obstructive sleep apnoea (OSA) is common in morbidly obese individuals. Sleep-disordered breathing is often undiagnosed, and its overall prevalence has been estimated as $9 \%$ for women and $24 \%$ for men aged 30-60 years [1,2]. Anaesthesiologists must be aware of the high prevalence of undiagnosed OSA in obese surgical patients $(>24 \%)[3,4]$.

OSA patients often have comorbid conditions and may also develop a systemic inflammatory state that predisposes them to cardiac and cerebrovascular events, such as coronary artery disease, heart failure, arrhythmias, strokes, and sudden cardiac death [5-8]. The importance of diagnosing and treating OSA in obese patients prior to surgery is widely recognized [9]. In OSA patients, preoperative CPAP improves exercise tolerance, and reduces daytime sleepiness and negative cardiopulmonary physiological consequences, especially hypertension [10-12]. 
For obese patients with OSA, the perioperative period is known to be challenging. The likelihood of post-surgical respiratory complications, including atelectasis, pneumonia, and hypoxia, is increased in all obese patients. OSA prevalence varies according to the type of surgery, peaking among bariatric surgery patients. As the number of patients undergoing weight loss surgery increases, more patients will be at risk for these potentially life-threatening postoperative pulmonary events $[3,13,14]$.

The aim of this prospective observational study was to identify the extent to which anthropometric and other objective measurements relevant to OSA can be used for the identification of significant OSA, defined as an Apnoea/Hypopnoea Index (AHI) of $\geq 20$.

\section{Materials and methods}

With institutional Ethical Committee approval and signed informed consent from patients, we prospectively studied 1357 consecutive patients who were scheduled for elective laparoscopic bariatric surgery in the Ponderas Hospital, Centre of Excellence for Bariatric and Metabolic Surgery, Bucharest, Romania, between January 2013 and December 2015. As an observational study, no intervention in medical protocols was applied and thus we analysed a cohort of obese patients who had agreed to bariatric surgery in that period.

All the patients, with ASA physical status I-IV, were assessed 3-4 weeks before surgery by a multidisciplinary team, which included an anaesthetist. In addition to the routine recording of body mass index (BMI), gender, presence of diabetes, neck circumference (NC), and $\mathrm{SpO}_{2}$ and administration of the STOP-Bang questionnaire, we measured neck fat, lean neck tissue, trunk fat, and lean trunk tissue using dual X-ray absorptiometry (Lunar iDXA, GE Healthcare Madison, WI). The iDXA system is a high-resolution densitometry that differentiates between bone and surrounding soft tissue, and further distinguishes the latter as fat and fat-free (lean) compartments. We measured the lung volumes by spirometry or lung plethysmography to all patients.

All patients with a STOP-Bang questionnaire score $\geq 5$ underwent polysomnography (PSG) with a 12channel portable PSG CID-LX type III device (CIDELEC, Sainte Gemmes/Loire, France) or SOMNOcheck micro (WEINMANN, Hamburg, Germany) type IIa device, at home.

The polysomnographic recording montage for the CID-LX consisted of a nasal cannula (to measure nasal flow), a PneaVoX sensor, thoracic and abdominal inductive belts, a polygraph placed on the wrist, and pulse oximetry. The Pnea VoX technology allows the recording of various physiological parameters with a single sensor: nose and mouth breathing, and respiratory efforts, discriminating obstructive, central, and mixed sleep apnoea, and snoring. In addition, upper airway resistance is estimated by measuring acoustic intensity. The signals allow detection of sleep apnoea and snoring, and characterization of the apnoea by suprasternal pressure. The device has an additional pressure channel for connecting a pneumotachograph when the patient is treated with CPAP or BiPAP.

The portable PSG device was connected to the patients by a PSG technician in hospital; patients were taught how to use the device at home for overnight recording. The PSG recordings were automatically analysed using CIDELEC or SOMNOlab software, and were further reviewed by a sleep physician. All PSG recordings were scored according to the recommendations of the American Society of Anesthesiologists Task Force on Perioperative Management of Patients with Obstructive Sleep Apnea [15].

According to the American Academy of Sleep Medicine, apnoea was defined as an at least $90 \%$ decrease in airflow from baseline, lasting at least $10 \mathrm{~s}$. Hypopnoea was defined as an at least $50 \%$ reduction in airflow, lasting at least $10 \mathrm{~s}$, and associated with at least a $3 \%$ decrease in arterial oxyhemoglobin saturation or associated with arousal [16]. AHI was defined as the average number of apnoea and hypopnoea episodes per hour, and the severity of OSA was graded based on AHI (none 0-5, mild OSA 6-20, moderate OSA 21-40, severe OSA $>40$ ) [15]. The oxygen desaturation index (ODI) was defined as the average number of episodes per hour, with $4 \%$ or greater desaturation and lasting $10 \mathrm{~s}$ or longer [17]. Minimal saturation during sleep was also recorded.

The anaesthesiologist decided on CPAP and oxygen therapy. CPAP therapy was indicated when AHI was $\geq 20 / \mathrm{h}, \mathrm{ODI} \geq 5$, and minimum saturation during sleep $<80 \%$.

The AutoCPAP (APAP)-GoodKnight 418 (Mallinckrodt Respiratory Group, St Louis, MO) and S8 AutoSet Spirit ${ }^{\text {TM }}$ II (ResMed, San Diego, CA) devices were used. Auto-titrated CPAP (APAP) measures the flow breath-by-breath, and adjusts the delivered pressure to the minimal level necessary for maintaining an unobstructed airway [18]; it allows initiation of treatment without in-laboratory CPAP titration $[12,19,20]$ and the pressure applied can vary $\pm 3 \mathrm{~cm} \mathrm{H} \mathrm{H}_{2} \mathrm{O}$ in response to changes in airway resistance. According to our hospital protocol, if pulse oxygen saturation $\left(\mathrm{SpO}_{2}\right)$ on oximetry in room air was $<90 \%$, oxygen therapy was provided.

\section{Statistical analysis}

Statistical analyses were performed with SPSS version 22 , and significance set to $p \leq 0.05$. The patient data are presented with descriptive statistics, as means 
and standard deviation or as medians and interquartile ranges, as appropriate. Normality of distribution was tested using the Shapiro-Wilk test. Categorical data were reported as frequencies and percentages, and compared using chi-square tests and odds ratios (ORs).

The relationship between different non-normal parameters was assessed by Spearman correlation. Logistic regression models were employed to identify predictors of OSA and the related probabilities. For each score in the 345 patients, we used $2 \times 2$ contingency tables to determine the sensitivity, specificity, positive-predictive values, negative-predictive values, likelihood ratios (LR), and post-test probabilities. For each parameter of interest, we constructed receiver operating curves (ROC) to determine the area under the curve (AUC). The cut-off point for each score was assessed using the de Youden Index and Matthew's Correlation Coefficient. After examining the AUC's and cut-off points for each variable, we constructed the new score, the Dual X-Ray-Obstructive Sleep Apnoea (DX-OSA) Score (which included the STOP-Bang score, BMI, neck fat, trunk fat, baseline $\mathrm{SpO}_{2}$, and Expiratory Reserve Volume [ERV]). If a patient had any parameter value greater or equal to the cut-off, we assigned the point-value 1 . The score had a minimal sum of 0 points and a maximum of 6 points (Table 1).

\section{Results}

A total of 1357 patients gave informed consent, and 345 patients with STOP-Bang scores $\geq 5(25.4 \%)$
Table 1. DX-OSA score

\begin{tabular}{lcc|}
\hline DX-OSA score & Cut-off & Points \\
\hline STOP-Bang & $\geq 5$ & 1 \\
BMI $\left(\mathrm{kg} / \mathrm{m}^{2}\right)$ & $\geq 45$ & 1 \\
Neck fat $(\mathrm{g})$ & $\geq 1330$ & 1 \\
Trunk fat $(\mathrm{kg})$ & $\geq 40$ & 1 \\
Baseline $\mathrm{SpO}_{2}(\%)$ & $\leq 94$ & 1 \\
Expiratory reserve volume (L) & $\leq 0.54$ or & 1 \\
Percent predicted (\%) & $\leq 40$ & \\
\hline
\end{tabular}

$\mathrm{BMI}$ - body mass index, $\mathrm{SpO}_{2}$ - pulse oximetry oxygen saturation

underwent PSG, while 190 patients (14\%) with AHI > 20/h received preoperative CPAP treatment. Patient assignment and study implementation are shown in the flow chart (Fig. 1) and the Table 2 gives the descriptive statistics for our patients.

We constructed ROC curves for our main variables of interest (Fig. 2). All had an AUC $>0.60$ for OSA diagnosis (range: $0.632-0.900 ; p<0.0001$ ). The AUC for the STOP-Bang score was $0.846(\mathrm{p}<0.0001)$, for the DX-OSA, $0.902(\mathrm{p}<0.0001)$ (Table 3). From these ROC curves, we chose the variables for our new score (Table 1). The best possible cut-off values for our parameters were determined (Table 4). The cut-off value for STOP-Bang was 5 points, and for DX-OSA 3 points, and these methods showed a significant agreement $\left(\mathrm{R}^{2}=1\right)$.

Table 3 summarizes the values obtained from the contingency tables for STOP-Bang and DX-OSA scores, at different cut-off values. The sensitivity for DX-OSA for a 3-point cut-off value was 0.768 while

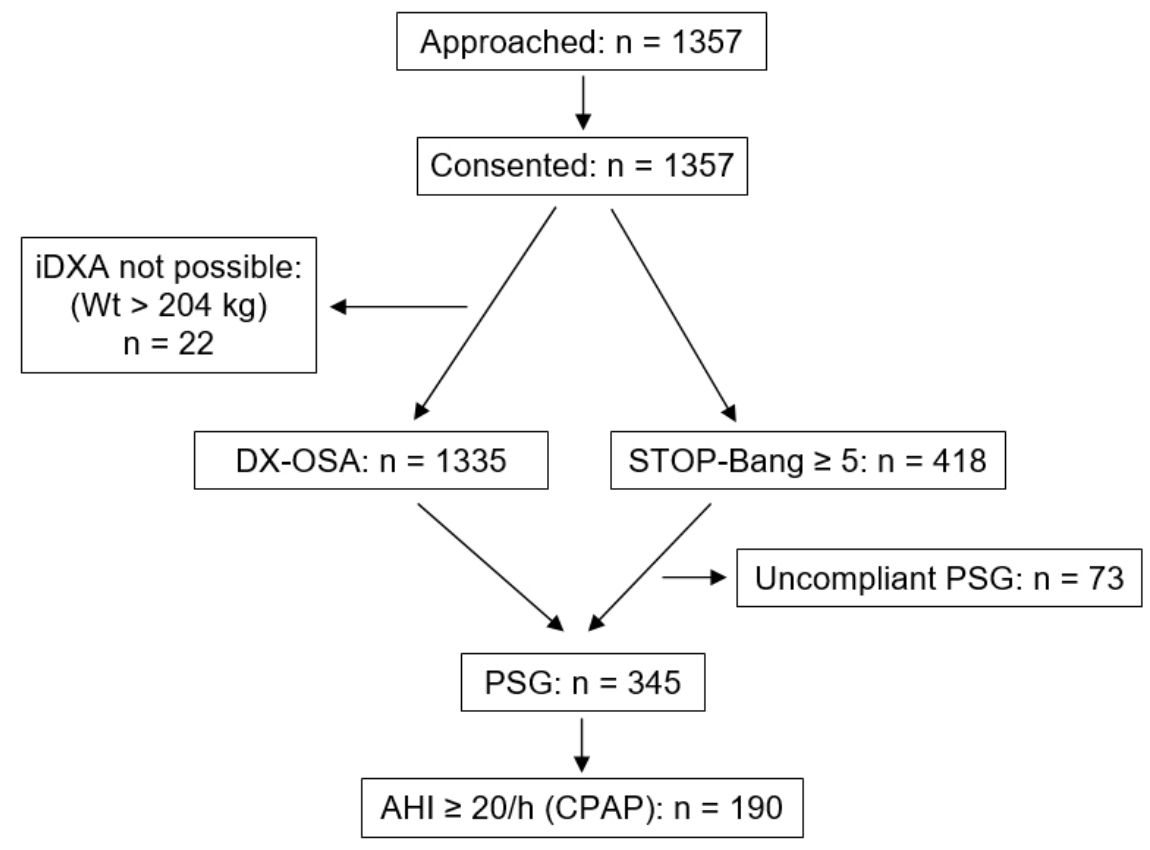

Fig. 1. Patient recruitment and follow-up flow chart. PSG = polysomnography. AHI - Apnea-Hipopnea Index; DX-OSA score = Dual X-Ray-Obstructive Sleep Apnoea score; iDXA = Dual X-ray Absorptiometry; Wt $=$ weight 


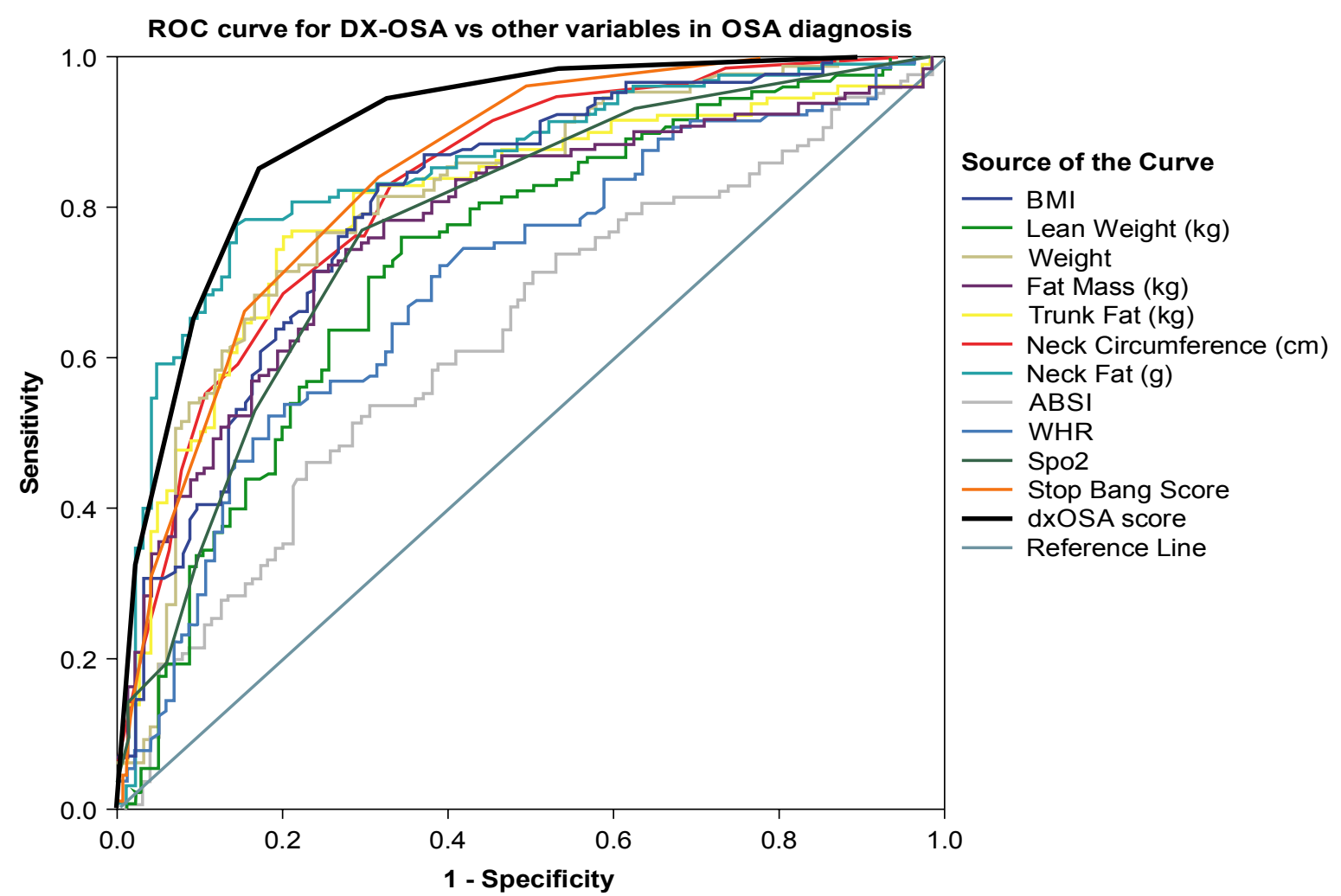

Fig. 2. Receiver operating characteristic curves for DX-OSA score vs main variables of interest in OSA. (BMI - body mass index, lean weight, fat mass, trunk fat, neck circumference, ABSI - A Body Shape Index; WHR - Waist-Hip Ratio, $\mathrm{SpO}_{2}-$ oxygen saturation, STOP-Bang score). The AUC for the DX-OSA was the highest -0.902 vs AUC for the STOP-Bang score - 0.846

Table 2. Descriptive statistics

\begin{tabular}{lccc}
\hline Variable & Median & $25 \%-75 \%$ percentile & IQR \\
\hline Age $(\mathrm{yr})$ & 42 & $34.0-49.0$ & 15.0 \\
$\mathrm{BMI}\left(\mathrm{kg} / \mathrm{m}^{2}\right)$ & 40.9 & $36.3-46.0$ & 8.8 \\
\hline Height $(\mathrm{cm})$ & 170 & $164-177$ & 14 \\
$\mathrm{SpO}_{2}$ baseline $(\%)$ & 0.97 & $0.96-0.98$ & 0.02 \\
\hline Lean weight $(\mathrm{kg})$ & 54.9 & $47.36-67.40$ & 19.70 \\
Fat mass $(\mathrm{kg})$ & 56.4 & $46.6-67.2$ & 20.0 \\
\hline Trunk fat $(\mathrm{kg})$ & 32.3 & $25.7-40.5$ & 13.5 \\
Neck fat $(\mathrm{g})$ & 1212.5 & $923.0-1579.7$ & 676.5 \\
\hline Lean neck $(\mathrm{kg})$ & 2.1 & $1.8-2.6$ & 0.96 \\
Expiratory reserve volume & 40.7 & $24.0-63.0$ & 39.7 \\
Percent predicted $(\%)$ & & & \\
\hline
\end{tabular}

$\mathrm{BMI}=$ body mass index; $\mathrm{IQR}=$ interquartile range; $\mathrm{SpO}_{2}-$ pulse oximetry oxygen saturation

Table 3. Cut-off values for different parameters in OSA diagnosis

\begin{tabular}{lcccc}
\hline Variable(s) & AUC & Std. Error & Cut-off value & P-value \\
\hline BMI $\left(\mathrm{kg} / \mathrm{m}^{2}\right)$ & 0.809 & 0.029 & 43.80 & $<0.0001$ \\
Lean weight $(\mathrm{kg})$ & 0.735 & 0.033 & 62.40 & $<0.0001$ \\
Actual weight $(\mathrm{kg})$ & 0.816 & 0.028 & 134.60 & $<0.0001$ \\
Fat mass $(\mathrm{kg})$ & 0.778 & 0.030 & 66.08 & $<0.0001$ \\
Trunk fat $(\mathrm{kg})$ & 0.809 & 0.029 & 39.22 & $<0.0001$ \\
Neck fat $(\mathrm{g})$ & 0.857 & 0.025 & 1329.50 & $<0.0001$ \\
$\mathrm{SpO}_{2}(\%)$ & 0.777 & 0.031 & 0.95 & $<0.0001$ \\
Expiratory reserve volume $(\%)$ & 0.661 & 0.079 & 0.55 & 0.050 \\
DX-OSA Score & 0.902 & 0.021 & 3.00 & $<0.0001$ \\
STOP-Bang Score & 0.846 & 0.026 & 5.00 & $<0.0001$ \\
\hline
\end{tabular}

$\mathrm{BMI}=$ body mass index; $\mathrm{SpO}_{2}-$ pulse oximetry oxygen saturation 
the specificity was 0.787 . Compared to the STOPBang score, the sensitivity for DX-OSA was $4.2 \%$ lower and the specificity was improved by $13.5 \%$ (Table 5).

The positive likelihood ratios for our chosen cut-off points ranged from 2.33 (STOP-Bang) to 3.61 (DXOSA), and the negative likelihood ratios from 0.25 to 0.29. The LR+/LR- of the DX-OSA score was 3.61/ 0.29 , and of the STOP-Bang, 2.33/0.29 (Table 5, Fig. 3).

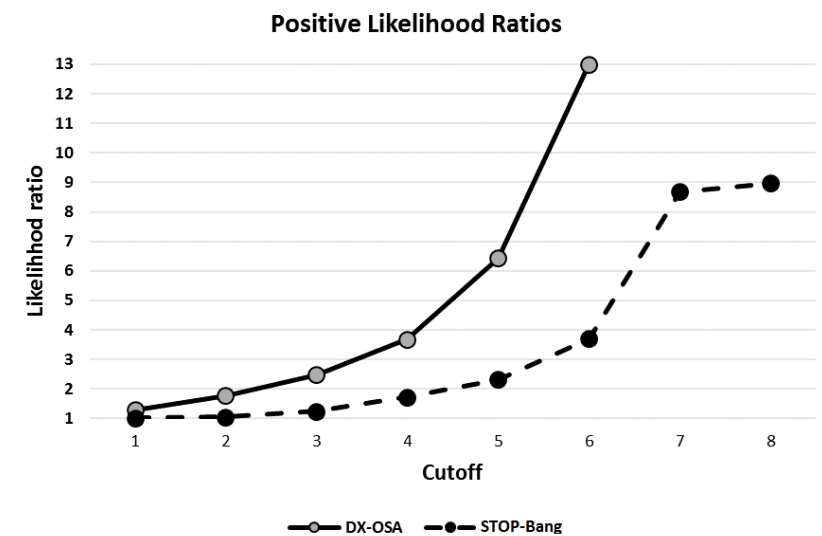

Fig. 3. The Positive Likelihood Ratios for OSA of DX-OSA score and STOP-Bang score. The positive likelihood ratios for our chosen cut-off points ranged from 2.33 (STOP-Bang), 3.61 (DX-OSA)
The positive-predictive values at the set cut-off points ranged from 0.74 (STOP-Bang) to 0.82 (DXOSA). The post-test probability for OSA diagnosis was $8 \%$ greater for the DX-OSA than for the STOP-Bang (post-test probability 0.74) (Table 5, Fig 4).

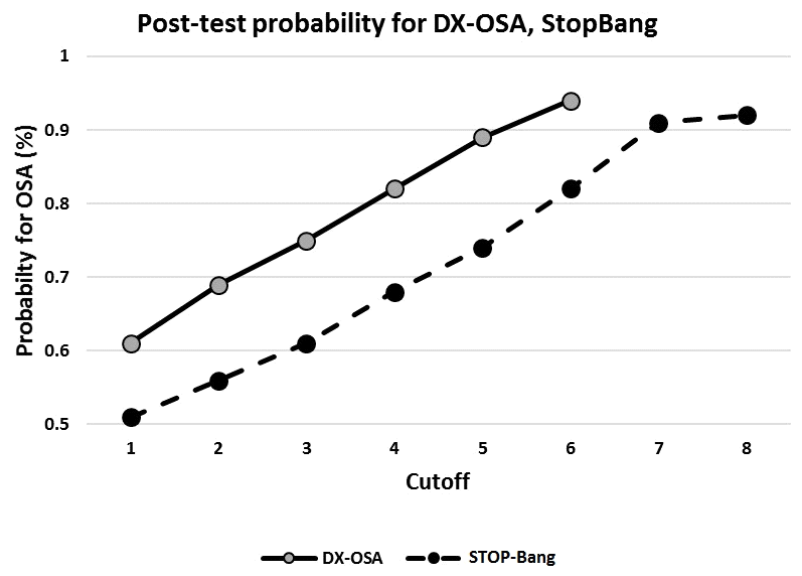

Fig. 4. The post-test probability for OSA of DX-OSA score and STOP-Bang score. The post-test probability for OSA diagnosis for: STOP-Bang - 0.74; DX-OSA (cut-off of 3) -0.83

In terms of ORs for identifying OSA, the DX-OSA had the greatest value (OR 15.02, $\mathrm{p}<0.0001,95 \% \mathrm{CI}$

Table 4. Correlation between Youden Index and Matthew's Correlation Coefficient in choosing the best cut-off score

\begin{tabular}{l|ll}
\hline $\begin{array}{l}\text { Youden Index } \\
\text { vs Matthew's Correlation Coefficient }\end{array}$ & $\mathrm{R}^{2}$ Linear* & Correlation equation \\
\hline STOP-Bang & 1 & $\mathrm{Y}=2.78 \mathrm{E}-17+0.71 \mathrm{x}$ \\
$\mathrm{BMI}$ & 1 & idem \\
\hline Neck fat & 1 & idem \\
Trunk fat & 1 & $\mathrm{Y}=-3.33 \mathrm{E}-16+1.41 \mathrm{x}$ \\
Baseline $\mathrm{SpO}_{2}$ & 1 & $\mathrm{Y}=1.41 \mathrm{x}$ \\
Expiratory reserve volume & 1 & idem \\
Neck circumference & 1 & idem \\
Waist circumference & 1 & $\mathrm{Y}=-8.33 \mathrm{E}-17+0.71 \mathrm{x}$ \\
\hline
\end{tabular}

$\mathrm{BMI}=$ body mass index; $* \mathrm{R}^{2}=1$, suggests perfect correlation

Table 5. Predictive scores for AHI $>20$

\begin{tabular}{|c|c|c|c|c|c|c|c|c|}
\hline & Cut-off & Sensitivity & Specificity & $\mathrm{LR}+$ & LR - & PPV & NPV & Post-test probability \\
\hline \multirow[t]{3}{*}{ DX-OSA } & 3 & 0.768 & 0.787 & $\begin{array}{c}3.61 \\
(2.64-4.93)\end{array}$ & $\begin{array}{c}0.29 \\
(0.22-0.39)\end{array}$ & 0.816 & 0.735 & $\begin{array}{c}0.82 \\
(0.76-0.86)\end{array}$ \\
\hline & 4 & 0.551 & 0.843 & $\begin{array}{c}3.51 \\
(2.38-5.17)\end{array}$ & $\begin{array}{c}0.53 \\
(0.45-0.63)\end{array}$ & 0.814 & 0.606 & $\begin{array}{c}0.83 \\
(0.74-0.86)\end{array}$ \\
\hline & 5 & 0.235 & 0.978 & $\begin{array}{c}11 \\
(3.63-31)\end{array}$ & $\begin{array}{c}0.78 \\
(0.72-0.85)\end{array}$ & 0.938 & 0.512 & $\begin{array}{c}0.93 \\
(0.82-0.97)\end{array}$ \\
\hline \multirow[t]{3}{*}{ STOP-Bang } & 4 & 0.937 & 0.458 & $\begin{array}{c}1.73 \\
(1.49-2.01)\end{array}$ & $\begin{array}{c}0.14 \\
(0.08-0.24)\end{array}$ & 0.679 & 0.855 & $\begin{array}{c}0.68 \\
(0.65-0.71)\end{array}$ \\
\hline & 5 & 0.811 & 0.652 & $\begin{array}{c}2.33 \\
(1.86-2.92)\end{array}$ & $\begin{array}{c}0.29 \\
(0.21-0.40)\end{array}$ & 0.740 & 0.737 & $\begin{array}{c}0.74 \\
(0.70-0.78)\end{array}$ \\
\hline & 6 & 0.621 & 0.832 & $\begin{array}{c}3.70 \\
(2.56-5.35)\end{array}$ & $\begin{array}{c}0.46 \\
(0.37-0.55)\end{array}$ & 0.819 & 0.642 & $\begin{array}{c}0.82 \\
(0.76-0.87)\end{array}$ \\
\hline
\end{tabular}

LR+/LR- = positive- and negative-likelihood ratios, $\mathrm{PPV}=$ positive-predictive value, $\mathrm{NPV}=$ negative predictive value 
8.51-26.1), and the STOP-Bang (OR 8, p $<0.0001$, 95\% CI 4.99-13.1). The Phi value, which presented additional information regarding the strength of association between the scores and OSA diagnosis, was 0.56 for DX-OSA, and 0.47 for STOP-Bang (Table 6 ), suggesting a strong association between the scores and OSA diagnosis.
$60 \%)[26,27]$. The STOP-Bang Questionnaire is the fastest to implement [23], and has a high sensitivity for identifying OSA in a preoperative setting [24]. However, given its moderate specificity, particularly for predicting moderate-severe OSA, the STOP-Bang questionnaire may produce a high number of falsepositives, leading to unnecessary referrals for sleep

Table 6. Odds ratios for DX-OSA, and STOP-Bang $\left(\div^{2}\right.$ test) in OSA diagnosis

\begin{tabular}{lcccc|}
\hline & Odds ratio & $95 \% \mathrm{CI}$ & Phi Correlation & P-value \\
\hline DX-OSA & 15.02 & $8.519-26.05$ & 0.558 & $<0.0001$ \\
STOP-Bang & 8.00 & $4.89-13.07$ & 0.470 & $<0.0001$ \\
\hline
\end{tabular}

We used a logistic regression model to determine whether our new score could predict OSA and found that the DX-OSA score was good predictor of OSA diagnosis $(\mathrm{p}<0.0001)$ (Fig. 5). We extracted the polynomial regression equation from the model, and calculated the increase in the probability of OSA with each point increase for the DX-OSA score, and found that each additional point increased the mean probability of OSA diagnosis by approximately $20 \%$.

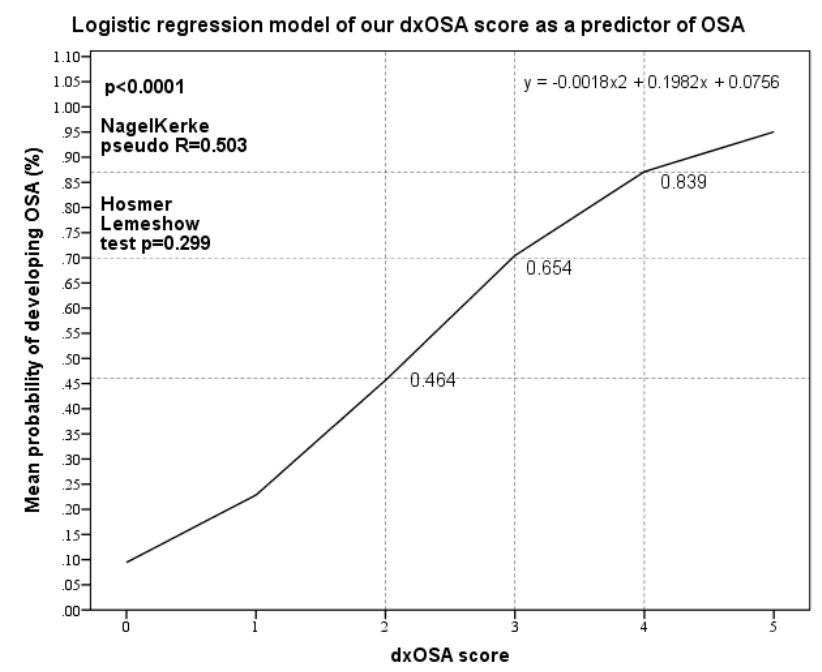

Fig. 5. Logistic regression model for DX-OSA score as a predictor of OSA $(\mathrm{AHI}>20 / \mathrm{h})$

\section{Discussion}

In morbidly obese individuals, a presumptive clinical diagnosis of OSA should be verified and its severity determined to establish the perioperative risk $[14,21]$. Three screening tools for identifying OSA in a preoperative setting [22] have been validated in surgical patients: the Berlin Questionnaire [4], the American Society of Anesthesiologists' Checklist [15], and the STOP-Bang Questionnaire [23-25]. Their sensitivity varies from 50 to $90 \%$, depending upon the OSA severity targeted, but all have suboptimal specificity (30- studies and increased cost [27]. Methods for improving its specificity, such as by combining it with elevated serum bicarbonate levels [28] or emphasizing more predictive items, such as male sex and BMI $>35$ have been proposed [29, 30]. Obesity is the most important factor in adult OSA, and OSA severity appears proportional to weight changes [1,31]. Farney et al. found that a weighted model for each STOP-Bang response can slightly improve prediction over a linear model [32]. Corso et al. used a STOP-Bang with cut-off of 5 to identify high-risk OSA patients; such patients had a higher rate of postoperative complications, difficult intubation, and difficult mask ventilation [33]. The cut-off of 5 was also considered by Chung et al. as the best compromise between specificity and sensitivity [26]. We therefore referred all the patients with a recorded STOP-Bang score $\geq 5$ for sleep studies to confirm OSA $[34,35]$.

In-laboratory PSG remains the gold-standard for OSA diagnosis [36]. Overnight polysomnography in a sleep laboratory over a period of 2 nights is recommended by the American Thoracic Society and the American Academy of Sleep Medicine for diagnosing OSA and initiating CPAP [16]. Portable home sleeptesting devices [37] or night oximetry [17] are possible alternatives for OSA diagnosis. However, cost, low availability in hospitals, and poor patient compliance, reduce their applicability for verifying an OSA diagnosis [33].

The utility of obtaining a formal preoperative OSA diagnosis by PSG and CPAP therapy, rather than by screening, remains unclear [38, 39]. Moreover Mulgrew at al. demonstrated, in 2007, in a randomized validation study, that during the initial management of patients with a high OSA probability of OSA likelihood, PSG confers no advantage over the OSA patients approach [20]. However, increasingly studies have shown the benefits of preoperative PAP therapy, particularly in the morbidly obese. In a randomized control trial, nasal CPAP has been shown to reduce 
the need for intubation, incidence of pneumonia, infection, and sepsis in patients who developed acute hypoxemia after elective major abdominal surgery [5, 11]. Liao et al. conducted the first trial that showed the feasibility of perioperative APAP for surgical patients with untreated OSA. Perioperative APAP treatment effectively decreases AHI and improves postoperative oxygen saturation in surgical patients with moderate and severe OSA [10]. APAP is equivalent to CPAP in efficacy, adherence, and functional outcomes, but delivers significantly lower pressure and has lower average leak values in the morbidly obese [12].

We here derived the clinical score - DX-OSA based on clinical objective measurements, to obtain more accurate diagnosis of moderate-severe OSA for referring patients for APAP without PSG testing. In our clinic, pre-anaesthetic assessment is performed by the same anaesthesiologist over a 1-week period, and 10-15 patients are seen per day. The anaesthetists screen the patients using the STOP-Bang questionnaire and have observed that some STOP-Bang items (STO) are subjective, and depend on patient-reporting; hence, many patients who could have been sent for PSG may therefore provide unreliable answers to such STO questions.

Although BMI alone is not a good predictor of sleep apnoea, BMI and OSA incidence are directly related. In severely obese patients (BMI $>40 \mathrm{~kg} / \mathrm{m}^{2}$ ) undergoing bariatric surgery, the prevalence of OSA is $>$ $70 \%$ (range: $40-90 \%$ ) [21, 26, 40]. After bariatric surgery and weight reduction, OSA significantly improves and may even be resolved [41, 42].

Gender also affects sleep apnoea. Males have a two- to threefold increased risk of OSA as compared to women [2], which may be related to differences in the distribution of adipose tissue in men [21, 43-45], who have a predominantly central fat deposition pattern around the neck, trunk, and abdominal viscera [46, 47].

For a given BMI, risk is affected by body shape, as a marker of central abdominal fat deposits [46-50] around the neck, trunk and abdominal viscera. Thus, $\mathrm{BMI}$ is augmented by other simple biometrics, as neck and trunk fat. We used iDXA for measuring neck and trunk fat $[51,52]$, which were included in the DXOSA score. iDXA is considered the gold standard for body composition measurements, easy and cheap, providing excellent precision for total body and regional fat distribution in severely obese individuals.

Simpson et al. first described sex differences in the associations between the severity of OSA [53, 54] and measures of obesity in body regions defined using both iDXA and traditional anthropometry. They found an association between regional obesity and OSA severity. In women, neck fat directly influenced upper airway patency, while in men, abdominal obesity was the predominant influence. iDXA measures of fat mass were more predictive of OSA severity than were anthropometric measures [3, 54]. Similarly, in our study, iDXA measurements well predicted OSA, as demonstrated the logistic regression model (Fig. 5). We found a strong association between neck and trunk fat, measured by iDXA and AHI as demonstrated the AUCs from Table 3.

Obesity affects ERV (expiratory reserve volume) due to premature closure of the small peripheral airways [55-58]. In turn, the reduction in end-expiratory lung volumes, which are accentuated in sleep, may lead to a reduction in the tracheal traction on the pharynx, increasing its collapsibility $[3,13,59]$. Therefore, we used ERV as an objective, easy-to-measure factor associated with severe OSA requiring pre- and postoperative PAP treatment.

Obesity is likely to be an important predictive variable for hypoxemia. The reduced ERV in obese subjects, especially in the recumbent posture, together with high tissue $\mathrm{O}_{2}$ consumption rates, cause more rapid depletion of lung $\mathrm{O}_{2}$ stores during apnoea, resulting in more severe arterial $\mathrm{O}_{2}$ desaturation for any given apnoeic length [60]. Patients with severe OSA have higher desaturation during wakefulness, nonREM sleep, REM sleep, and during obstructive events [61]. Paradoxically, the severity of OSA was not quantified using indices of hypoxemia during sleep, which may predict hypertension risk more accurately than does AHI. Overnight hypoxemia is considered to underline the cardiovascular impact of OSA, involving increased morning catecholamine levels and increased thrombotic risk [60-62]. We considered baseline $\mathrm{SpO}_{2}$ measurement and hypoxemia (daytime or nocturnal) the best outcome-indicators of OSA severity where intervention with PAP is crucial and included $\mathrm{SpO}_{2}$ in the new scores.

In our study, we used a cut-off of 5 for the STOPBang score [33, 63]. Three-hundred-and-forty-five from 418 patients $(82 \%)$ with a STOP-Bang $\geq 5$ were studied with formal PSG, but only 190 patients had OSA requiring CPAP treatment. Thus, $>50 \%$ of the results were false-positives or significant OSA (AHI $>20 /$ h).

We evaluated the predictive performance of DXOSA score for diagnosing OSA in obese and morbidly obese surgical patients. The DX-OSA score has a weight limit, due to the practical drawbacks of the iDXA measurements: there are physical limits to body weight (204 kg), length, thickness, and width that can be determined with the type of DXA machine, while availability may be another limitation [46]. Twenty-two of the patients in this study had body weight $>204 \mathrm{~kg}$; they could not be screened and were considered high risk on clinical grounds. 
Hence all results for this score were even lower, as 22 patients with a weight $>204 \mathrm{~kg}$ were included in the CPAP treatment cohort. The score (with a cut-off of 3) improved specificity to $80 \%$ at the same sensitivity as a STOP-Bang score of 5, with an increased likelihood ratio and a better post-test probability $(80 \%)$. We included the STOP-Bang in the score, which may have biased our objective approach. However, we tested all combinations of the new score items to assess the statistical significance, and found promising results. We also tested for correlation between parameters within our scores, all of them being statistically significant with a Spearman correlation coefficient that ranged from 0.161 to 0.535 . DX-OSA score boosted the AUC, sensitivity and specificity, thus allowing a better selection of patients who received preoperative CPAP. The DX-OSA score consists of objective measurements related to morbid obesity such as BMI, neck fat, trunk fat, ERV and baseline $\mathrm{SpO}_{2}$, except the STOP-Bang score that is used to screen the OSA in general. If the STOP-Bang is equivocal (3-4), any three associated items could improve the accuracy of the diagnosis of significant OSA that requires CPAP treatment. Therefore the score may be useful to find among the morbidly obese with OSA who need preoperative CPAP.

Our study has limitations. Although we included a large number of patients, this was a single-center observational study, and needs further validation. Nevertheless, this is the first study to identify a combination of objective clinical items that by themselves can provide a post-test probability of OSA $>80 \%$ and an increased likelihood ratio of moderate-severe OSA amongst the obese surgical population. Although the STOP-Bang score was clinically validated as a triage tool for OSA diagnosis, it cannot be used alone for implementing CPAP therapy without PSG, as it can under- or overestimate the presence of OSA requiring PAP therapy.

Once the patients have been screened using the STOP-Bang questionnaire, the routine use of the DXOSA score can indicate a very high probability of moderate OSA, requiring immediate APAP treatment, which can resolve problems, such as inefficient allocation of resources, access to or compliance of patients with PSG, and thereby save time. The DX-OSA score can form part of strategies for expediting diagnosis and safe CPAP treatment for OSA in obese surgical patients.

\section{Conclusions}

Obese surgical patients can be screened for OSA severity using the STOP-Bang questionnaire, which has been validated and is easy to use. The clinical objective measurements in the DX-OSA score could more specifically predict the presence of significant OSA, reducing false-positives and unnecessary referrals for PSG or overcrowding postoperative care units. Moreover, in conjunction with STOP-Bang screening, this score could improve the accuracy of decisionmaking for patients in the grey zone (STOP-Bang score of 3-6). Ultimately, if the combined clinical scales of the DX-OSA score are applied in a preoperative setting, a pre-test probability of OSA $\geq 85 \%$ can be derived, and CPAP can be implemented without the need for PSG, avoiding surgical delay. The new anthropometric score should be prospectively validated in future larger studies.

\section{Conflict of interest}

Nothing to declare

\section{Funding statement}

No funding received from Ministry of Health (Romania), Ponderas Hospital, or any other Romanian institution

\section{Acknowledgements}

The authors gratefully acknowledge the support of Dr. Michael Margarson (Consultant Anaesthetist, MB, BS, MD, FRCA, Dipl ICM, FFICM St. Richards Hospital, Chichester UK) who kindly contributed to the naming of the score DXOSA and provided thoughtful comments on the drafting of this manuscript. In addition, we thank Ms. Andreea Constantinescu (Assistant Secretary in Ponderas Hospital, Bucharest, Romania) who helped collect the data. Logistic support was provided from institutional and/or departmental sources in Ponderas Hospital. Finally, we would like to thank Editage (www.editage.com) for English language editing.

\section{References}

1. Young T, Peppard PE, Taheri S. Excess weight and sleepdisordered breathing. J Appl Physiol 2005; 99: 1592-1599. DOI: 10.1152/japplphysiol.00587.2005

2. Young T, Peppard PE, Gottlieb DJ. Epidemiology of obstructive sleep apnea: a population health perspective. Am J Respir Crit Care Med 2002; 165: 1217-1239

3. Isono S. Obstructive sleep apnea of obese adults: pathophysiology and perioperative airway management. Anesthesiology 2009; 110: 908-921. DOI: 10.1097/ALN.0b013e31819c74be

4. Chung F, Ward B, Ho J, Yuan H, Kayumov L, Shapiro C. Preoperative identification of sleep apnea risk in elective surgical patients, using the Berlin questionnaire. J Clin Anesth 2007; 19: 130-134. DOI: 10.1016/j.jclinane.2006.08.006

5. Vasu TS, Doghramji K, Cavallazzi R, Grewal R, Hirani A, Leiby $\mathrm{B}$, et al. Obstructive sleep apnea syndrome and postoperative complications: clinical use of the STOP-BANG questionnaire. Arch Otolaryngol Head Neck Surg 2010; 136: 1020-1024. DOI: 10.1001/archoto. 2010.1020

6. Chia P, Seet E, Macachor JD, Iyer US, Wu D. The association of pre-operative STOP-BANG scores with postoperative critical care admission. Anaesthesia 2013; 68: 950-952. DOI: 10.1111/ anae. 12369

7. Abdelsattar ZM, Hendren S, Wong SL, Campbell DA Jr, Ramachandran SK. The impact of untreated obstructive sleep 
apnea on cardiopulmonary complications in general and vascular surgery: a cohort study. Sleep 2015; 38: 1205-1210. DOI: 10.5665/sleep. 4892

8. Mutter TC, Chateau D, Moffatt M, Ramsey C, Roos LL, Kryger M. A matched cohort study of postoperative outcomes in obstructive sleep apnea: could preoperative diagnosis and treatment prevent complications? Anesthesiology 2014; 121: 707-718. DOI: 10.1097/ALN.0000000000000407

9. Ebert TJ, Novalija J. Morbid Obesity and Obstructive Sleep Apnea: The Challenging Link. Open Anesthesiol J 2011; 5: 1922. DOI: $10.2174 / 1874321801105010019$

10. Liao P, Luo Q, Elsaid H, Kang W, Shapiro CM, Chung F. Perioperative auto-titrated continuous positive airway pressure treatment in surgical patients with obstructive sleep apnea: a randomized controlled trial. Anesthesiology 2013; 119: 837847. DOI: 10.1097/ALN.0b013e318297d89a

11. Squadrone V, Coha M, Cerutti E, Schellino MM, Biolino P, Occela $\mathrm{P}$, et al. Continuous positive airway pressure for treatment of postoperative hypoxemia: a randomized controlled trial. JAMA 2005; 293: 589-595. DOI: 10.1001/jama.293.5.589

12. Kushida CA, Berry RB, Blau A, Crabtree T, Fietze I, Kryger MH, et al. Positive airway pressure initiation: a randomized controlled trial to assess the impact of therapy mode and titration process on efficacy, adherence, and outcomes. Sleep 2011; 34: 1083 1092. DOI: $10.5665 /$ SLEEP. 1166

13. Punjabi NM, Caffo BS, Goodwin JL, Gottlieb DJ, Newman AB, O'Connor GT, et al. Sleep-disordered breathing and mortality: a prospective cohort study. PLoS Medicine 2009; 6: e1000132. DOI: 10.1371/journal.pmed.1000132

14. Romero-Corral A, Caples SM, Lopez-Jimenez F, Somers VK. Interactions between obesity and obstructive sleep apnea: implications for treatment. Chest 2010; 137: 711-719. DOI: 10.1378/chest.09-0360

15. American Society of Anesthesiologists Task Force on Perioperative Management of patients with obstructive sleep apnea. Practice guidelines for the perioperative management of patients with obstructive sleep apnea: an updated report by the American Society of Anesthesiologists Task Force on Perioperative Management of patients with obstructive sleep apnea. Anesthesiology 2014; 120: 268-286. DOI: 10.1097/ALN. 0000000000000053

16. Iber C, Ancoli-Israel S, Chesson A, Quan SF. The AASM Manual for the Scoring of Sleep and Associated Events: Rules, Terminology and Technical Specifications. Westchester (IL): American Academy of Sleep Medicine; 2007.

17. Chung F, Liao P, Elsaid H, Islam S, Shapiro CM, Sun Y. Oxygen desaturation index from nocturnal oximetry: a sensitive and specific tool to detect sleep-disordered breathing in surgical patients. Anesth Analg 2012; 114: 993-1000. DOI: 10.1213/ ANE.0b013e318248f4f5

18. Liao P, Luo Q, Elsaid HE, Kang W, Shapiro CM, Chung F. Perioperative auto-titrated continuous positive airway pressure treatment in surgical patients with obstructive sleep apnea: a randomized controlled trial. Anesthesiology 2013; 119: 837847. DOI: $10.1097 /$ ALN.0b013e318297d89a

19. Masa JF, Jiménez A, Durán J, Capote F, Monasterio C, Mayos $\mathrm{M}$, et al. Alternative methods of titrating continuous positive airway pressure: a large multicenter study. Am J Respir Crit Care Med 2004; 170: 1218-1224. DOI: 10.1164/rccm.200312$17870 \mathrm{C}$

20. Mulgrew AT, Fox N, Ayas NT, Ryan CF. Diagnosis and initial management of obstructive sleep apnea without polysom- nography: a randomized validation study. Ann Intern Med 2007; 146: $157-166$

21. Schwartz AR, Patil SP, Laffan AM, Polotsky V, Schneider H, Smith PL. Obesity and obstructive sleep apnea: pathogenic mechanisms and therapeutic approaches. Proc Am Thorac Soc 2008; 5: 185-192. DOI: 10.1513/pats.200708-137MG

22. Minokadeh A, Bishop LM, Benumof LJ. Obstructive sleep apnea, anaesthesia and ambulatory surgery. Anaesthesiology news manual guide to airway management 2011: 72-78

23. Chung F, Yegneswaran B, Liao P, Chung SA, Vairavanathan S, Islam S, et al. STOP questionnaire: a tool to screen patients for obstructive sleep apnea. Anesthesiology 2008; 108: 812-821. DOI: $10.1097 / A L N .0 b 013 \mathrm{e} 31816 \mathrm{~d} 83 \mathrm{e} 4$

24. Chung F, Subramanyam R, Liao P, Sasaki E, Shapiro C, Sun Y. High STOP-Bang score indicates a high probability of obstructive sleep apnoea. Br J Anaesth 2012; 108: 768-775. DOI: 10.1093/ bja/aes022

25. Chung F, Abdullah HR, Liao P. STOP-Bang Questionnaire: A Practical Approach to Screen for Obstructive Sleep Apnea. Chest 2016; 149: 631-638. DOI: 10.1378/chest.15-0903

26. Abrishami A, Khajehdehi A, Chung F. A systematic review of screening questionnaires for obstructive sleep apnea. Can J Anaesth 2010: 57: 423-438. DOI: 10.1007/s12630-010-9280-x

27. Gross JB, Bachenberg KL, Benumof JL, Caplan RA, Connis RT, Coté $\mathrm{CJ}$, et al. Practice guidelines for the perioperative management of patients with obstructive sleep apnea: a report by the American Society of Anaesthesiologists Task Force on Perioperative Management of patients with obstructive sleep apnea. Anesthesiology 2006; 104: 1081-1093

28. Chung F, Chau E, Yang Y, Liao P, Hall R, Mokhlesi B. Serum bicarbonate level improves specificity of STOP-Bang screening for obstructive sleep apnea. Chest 2013; 143: 1284-1293. DOI: 10.1378/chest.12-1132

29. Chung F, Yang Y, Brown R, Liao P. Alternative scoring models of STOP-Bang questionnaire improve specificity to detect undiagnosed obstructive sleep apnea. J Clin Sleep Med 2014; 10: 951-958. DOI: $10.5664 / \mathrm{jcsm} .4022$

30. Chung F, Yang Y, Liao P. Predictive performance of the STOPBang score for identifying obstructive sleep apnea in obese patients. Obes Surg 2013; 23: 2050-2057. DOI: 10.1007/ s11695-013-1006-z

31. Newman AB, Foster G, Givelber R, Nieto FJ, Redline S, Young T. Progression and regression of sleep-disordered breathing with changes in weight: the Sleep Heart Health Study. Arch Intern Med 2005; 165: 2408-2413. DOI: 10.1001/ archinte. 165.20.2408

32. Farney RJ, Walker BS, Farney RM, Snow GL, Walker JM. The STOP-Bang equivalent model and prediction of severity of obstructive sleep apnea: relation to polysomnographic measurements of the apnea/hypopnea index. J Clin Sleep Med 2011; 7: 459-465. DOI: 10.5664/JCSM.1306

33. Corso RM, Petrini F, Buccioli M, Nanni O, Carretta E, Trolio A, et al. Clinical utility of preoperative screening with STOPBang questionnaire in elective surgery. Minerva Anestesiol 2014; 80: $877-884$

34. Seet E, Chung F. Management of sleep apnea in adults functional algorithms for the perioperative period: Continuing Professional Development. Can J Anaesth 2010; 57: 849-864. DOI: $10.1007 / \mathrm{s} 12630-010-9344-\mathrm{y}$

35. Gali B, Whalen FX, Schroeder DR, Gay PC, Plevak DJ. Identification of patients at risk for postoperative respiratory complications using a preoperative obstructive sleep apnea 
screening tool and postanesthesia care assessment. Anesthesiology 2009; 110: 869-877. DOI: 10.1097/ALN.0b013e31819b $5 \mathrm{~d} 70$

36. Fleetham J, Ayas N, Bradley D, Ferguson K, Fitzpatrick M, George C, et al. Canadian Thoracic Society guidelines: diagnosis and treatment of sleep disordered breathing in adults. Can Respir J 2006; 13: 387-392

37. Chung F, Liao P, Sun Y, Amirshahi B, Fazel H, Shapiro CM, et al. Perioperative practical experiences in using a level 2 portable polysomnography. Sleep Breath 2011; 15: 367-375. DOI: 10.1007/s11325-010-0340-9

38. Corda L, Redolfi S, Montemurro LT, La Piana GE, Bertella E, Tantucci C. Short- and long-term effects of CPAP on upper airway anatomy and collapsibility in OSAH. Sleep Breath 2009; 13: 187-193. DOI: $10.1007 / \mathrm{s} 11325-008-0219-1$

39. Bolden N, Smith CE, Auckley D, Makarski J, Avula R. Perioperative complications during use of an obstructive sleep apnea protocol following surgery and anesthesia. Anesth Analg 2007; 105: 1869-1870. DOI: 10.1213/01.ane.0000295223.31946.b5

40. Dixon JB, Schachter LM, O'Brien PE. Polysomnography before and after weight loss in obese patients with severe sleep apnea. Int J Obes (Lond) 2005; 29: 1048-1054. DOI: 10.1038/ sj.ijo.0802960

41. Fritscher LG, Mottin CC, Canani S, Chatkin JM. Obesity and obstructive sleep apnea-hypopnea syndrome: the impact of bariatric surgery. Obes Surg 2007; 17: 95-99. DOI: 10.1007/ s11695-007-9012-7

42. Buchwald H, Avidor Y, Braunwald E, Jensen MD, Pories W, Fahrbach K, et al. Bariatric surgery: a systematic review and meta-analysis. JAMA 2004; 292: 1724-1737. DOI: 10.1001/ jama.292.14.1724

43. Vgontzas AN, Papanicolaou DA, Bixler EO, Hopper K, Lotsikas A, Lin HM, et al. Sleep apnea and daytime sleepiness and fatigue: relation to visceral obesity, insulin resistance, and hypercytokinemia. J Clin Endocrinol Metab 2000; 85: 11511158. DOI: $10.1210 /$ jcem.85.3.6484

44. Millman RP, Carlisle CC, McGarvey ST, Eveloff SE, Levinson PD. Body fat distribution and sleep apnea severity in women. Chest 1995; 107: 362-366

45. Dancey DR, Hanly PJ, Soong C, Lee B, Shepard J Jr, Hoffstein V. Gender differences in sleep apnea: the role of neck circumference. Chest 2003; 123: 1544-1550

46. Chumlea C. Body Composition Assessment of Obesity. In: Bray GA, Ryan DH, eds. Overweight and the Metabolic Syndrome: From Bench to Bedside. Series: Book Endocrine Updates, Volume 26. New York: Springer-Verlag US; 2006: 23-35

47. Chumlea WC, Roche AF, Webb P. Body size, subcutaneous fatness and total body fat in older adults. Int J Obes 1984; 8: 311-317

48. Ballesteros-Pomar MD, Calleja-Fernández A, Diez-Rodríguez R, Vidal-Casariego A, Blanco-Suárez MD, Cano-Rodríguez I. Comparison of different body composition measurements in severely obese patients in the clinical setting. Nutr Hosp 2012; 27: 1626-1630. DOI: 10.3305/nh.2012.27.5.5989

49. Lovin S, Bercea R, Cojocaru C, Rusu G, Mihăescu T. Body composition in obstructive sleep apnea-hypopnea syndrome bio-impedance reflects the severity of sleep apnea. Multidiscip Respir Med 2010; 5: 44-49. DOI: 10.1186/2049-6958-5-1-44

50. Whittle A T, Marshall I, Mortimore IL, Wraith PK, Sellar RJ, Douglas NJ. Neck soft tissue and fat distribution: comparison between normal men and women by magnetic resonance imaging. Thorax 1999; 54: 323-328

51. Hind K, Oldroyd B, Truscott JG. In vivo precision of the GE Lunar iDXA densitometer for the measurement of total body composition and fat distribution in adults. Eur J Clin Nutr 2011; 65: 140-142. DOI: $10.1038 /$ ejen.2010.190

52. Carver TE, Christou NV, Andersen RE. In vivo precision of the GE iDXA for the assessment of total body composition and fat distribution in severely obese patients. Obesity (Silver Spring) 2013; 21: 1367-1369. DOI: 10.1002/oby.20323

53. Simpson L, Mukherjee S, Cooper MN, Ward KL, Lee JD, Fedson $\mathrm{AC}$, et al. Sex differences in the association of regional fat distribution with the severity of obstructive sleep apnea. Sleep 2010; 33: 467-474

54. Lim YH, Choi J, Kim KR, Shin J, Hwang KG, Ryu S, et al. Sexspecific characteristics of anthropometry in patients with obstructive sleep apnea: neck circumference and waist-hip ratio. Ann Otol Rhinol Laryngol 2014; 123: 517-523. DOI: 10.1177/ 0003489414526134

55. Sériès F, Cormier Y, La Forge J. Role of lung volumes in sleep apnoea-related oxygen desaturation. Eur Respir J 1989; 2: 26-30

56. Reis R, Antunes A. Lung volumes in the pathogenesis of obstructive sleep apnea. Rev Port Pneumol 2014; 20: 173-174. DOI: $10.1016 /$ j.rppneu.2014.01.005

57. Schwab RJ, Pasirstein M, Pierson R, Mackley A, Hachadoorian $\mathrm{R}$, Arens $\mathrm{R}$, et al. Identification of upper airway anatomic risk factors for obstructive sleep apnea with volumetric magnetic resonance imaging. Am J Respir Crit Care Med 2003; 168: 522530. DOI: $10.1164 / \mathrm{rccm} .200208-866$ OC

58. Bedell GN, Wilson WR, Seebohm PM. Pulmonary function in obese persons. J Clin Invest 1958; 37: 1049-1060. DOI: 10.1172/JCI103686

59. Hoffstein V, Zamel N, Phillipson EA. Lung volume dependence of pharyngeal cross-sectional area in patients with obstructive sleep apnea. Am Rev Respir Dis 1984; 130: 175-178. DOI: 10.1164/arrd.1984.130.2.175

60. Harman EM, Wynne JW, Block AJ. The effect of weight loss on sleep-disordered breathing and oxygen desaturation in morbidly obese men. Chest 1982; 82: 291-294

61. Bazurto Zapata MA, Dueñas Meza E, Jaramillo C, Maldonado Gomez D, Torres Duque C. Sleep apnea and oxygen saturation in adults at $2640 \mathrm{~m}$ above sea level. Sleep Sci 2014; 7: 103-106. DOI: $10.1016 /$ j.slsci.2014.09.003

62. Kalra M, Inge T, Garcia V, Daniels S, Lawson L, Curti R, et al. Obstructive sleep apnea in extremely overweight adolescents undergoing bariatric surgery. Obes Res 2005; 13: 1175-1179. DOI: $10.1038 /$ oby.2005.139

63. Corso RM, Petrini F, Sorbello M, Maitan S. STOP-Bang questionnaire in the perioperative setting: striving for continuous improvement. Minerva Anestesiol 2016; 82: 606

\section{Identificarea sindromului de apnee în somn de tip obstructiv semnificativ la pacientul obez: elaborarea noului scor DX-OSA}

\section{Rezumat}

Obiective. Constatăm o prevalență crescută a sindromului de apnee în somn de tip obstructiv (OSA) la pacienții chirurgicali obezi. Am studiat în ce măsură măsurătorile antropometrice pot fi utilizate cu scopul identificării OSA semnificativ (Index de Apnee/ Hipopnee $(\mathrm{AHI} \geq 20)$ la pacienții adulți chirurgicali. 
Material şi metodă. Am studiat în mod prospectiv 1357 de pacienți adulţi programați pentru chirurgie bariatrică laparoscopică. S-au înregistrat preoperator: indicele de masă corporală (BMI), sexul, circumferința gâtului, scorul STOP-Bang, $\mathrm{SpO}_{2}$, şi grăsimea gâtului şi trunchiului cu absorbțiometrie duală cu raze $\mathrm{X}(\mathrm{DX})$. Toți pacienții cu scor STOP-Bang $\geq 5$ au fost supuşi ulterior polisomnografiei. Ventilația cu presiune pozitivă auto-titrată (APAP) a fost instituită când $\mathrm{AHI} \geq 20 / \mathrm{h}$. $\mathrm{Au}$ fost identificați predictorii OSA şi au fost stabilite valorile prag, predictive.

Rezultate. Au fost înregistrați un total de 1357 pacienţi din care 345 au efectuat polisomnografie preoperatorie, iar 190 au avut AHI $\geq 20 / \mathrm{h}$ şi au fost supuşi terapiei APAP. Noul scor RX dual - sindrom de apnee în somn de tip obstructiv (DX-OSA) a fost elaborat prin utilizarea datelor măsurate la aceşti pacienți. Scorul a inclus 6 criterii: scorul STOP-Bang, BMI, grăsimea gâtului, grăsimea trunchiului, valoarea
$\mathrm{SpO}_{2}$ bazală şi volumul expirator de rezervă (ERV). S-au determinat apoi senzitivitatea şi specificitatea acestui scor, valorile predictive pozitive şi negative, rapoartele de risc şi probabilitățile post-test ale acestui scor calculat. La o valoare prag de 3 scorul DX-OSA a prezentat aceeaşi senzitivitate ca şi scorul STOPBang, dar cu o specificitate superioară. Cel mai redus raport de risc a fost decelat pentru STOP-Bang, iar cel mai ridicat pentru scorul DX-OSA (probabilitate OSA $>83 \%$ ).

Concluzii. Scorul DX-OSA ar putea fi util pentru identificarea pacienților obezi cu OSA semnificativ care necesită CPAP (presiune pozitivă continuă în căile aeriene). Astfel CPAP ar putea fi demarat fără a mai efectua polisomnografia şi fără a mai întârzia intervenția chirurgicală.

Cuvinte cheie: sindrom de apnee în somn de tip obstructiv, obezitate, presiune pozitivă continuă în căile aeriene 